FORMAS DE COIBIR O ABUSO DO PODER DE CONTROLE NAS SOCIEDADES ANÔNIMAS

\author{
Dissertação de Mestrado \\ Orientadora: Paula Andrea Forgioni
}

Universidade de São Paulo

Faculdade de Direito

Departamento de Direito Comercial

São Paulo 


\title{
FORMAS DE COIBIR O ABUSO DO PODER DE CONTROLE NAS SOCIEDADES ANÔNIMAS
}

\author{
Dissertação de Mestrado
}

\begin{abstract}
Dissertação apresentada à Banca Examinadora do Programa de PósGraduação em Direito, da Faculdade de Direito da Universidade de São Paulo, como exigência parcial para obtenção do Título de Mestre em Direito, na área de concentração Direito Comercial, sob a orientação da Professora Titular Doutora Paula Andrea Forgioni.
\end{abstract}

São Paulo 
Cunha, Lucas Marsili da,1978 -

Formas de coibir o abuso do poder de controle nas sociedades anônimas/ Lucas Marsili da Cunha: Paula Andra Forgiani - São Paulo, 2018.

$221 \mathrm{p}$.

Dissertação de Mestrado Pós-Graduação Strictu sensu - Faculdade de Direito - Universidade de São Paulo - São Paulo, 2018.

1. Direito Societário. 2. Lei 6.404/1976. 3. Abuso de poder de controle. I. FORGIONI, Paula Andrea, orientadora II. Título. 


\section{Banca Examinadora:}

Orientadora: Professora Titular Doutora Paula Andrea Forgioni

Professor(a):

Professor(a):

Professor(a): 
Dedico este trabalho a duas pessoas: ao meu falecido pai, que sempre me incentivou a estudar e que, com certeza, ficaria muito feliz em saber que após inúmeras pedras no caminho e muita superação eu consegui estudar na área que eu amo, na faculdade que ele sempre admirou, e à minha esposa Kátia, pelo apoio e compreensão durante esta etapa da vida, voltada para o aprofundamento nos estudos do Direito Comercial, que teve seu preço no que concerne ao nosso relacionamento, mas que com certeza valeu a pena. 
Agradeço primeiramente a Deus, por tudo o que vem sendo construído em minha vida. À minha família, por todo o apoio, em especial às minhas companheiras diárias Kátia e Maggie. Ao Doutor Alexandre de Moraes e ao Doutor Laerte José Castro Sampaio, por todo o aprendizado durante o convívio profissional, em especial no período de ingresso na pós-graduação. Aos demais colegas de escritório que sempre me apoiaram, em especial meus amigos Rodrigo Funabashi e Guilherme de Toledo Benazzi. A todos os professores da faculdade que me ensinaram tanto nas matérias que cursei: Eduardo Secchi Munhoz, Calixto Salomão Filho, José Marcelo Martins Proença, Mauro Rodrigues Penteado e Rodrigo Mendes Bróglia. Agradeço também aos professores convidados Arthur Barrinuevo e Wanderley Fernandes pelo auxílio prestado.

Aos meus colegas que durante os cursos contribuíram para o meu aprendizado, em especial meus amigos colegas de monitoria.

Um agradecimento especial à minha orientadora, Professora Paula Andrea Forgioni, pelo zelo e prontidão em me auxiliar na elaboração deste trabalho. No entanto, meu agradecimento vai além. Antes de conhecê-la, eu me considerava um apaixonado pelo Direito Comercial. E, após algumas conversas com a Professora Paula, eu constatei que pouco sabia e que havia um universo inteiro para conhecer. Ela me indicou uma vasta bibliografia que mudou minha forma de ver a matéria e me estimulou a estudar cada vez mais. Esse desafio e oportunidade não têm preço. Serei eternamente grato. 


\section{SUMÁRIO}

INTRODUÇÃO 9

\section{CAPÍTULO 10 PODER DE CONTROLE E SEU TRATAMENTO NA LEI 6.404/1974}

1.1 A criação da Lei 6.404/1974 e a inserção da figura do acionista controlador no

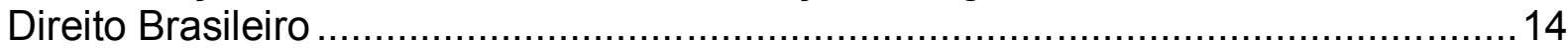

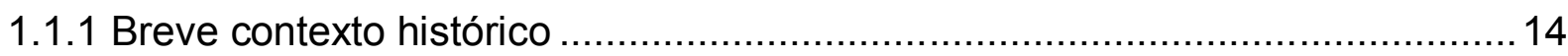

1.1.2 A inclusão da figura do controlador no ordenamento jurídico brasileiro ...........20

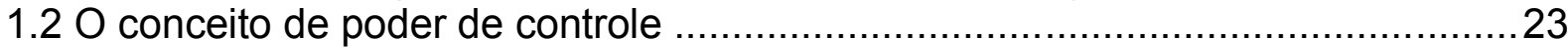

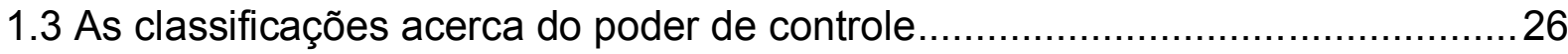

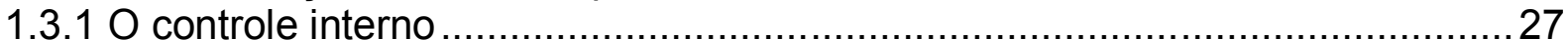

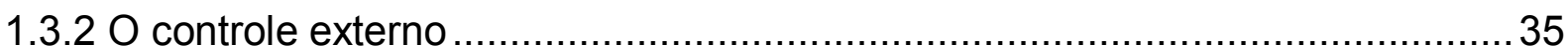

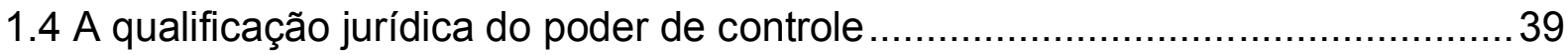

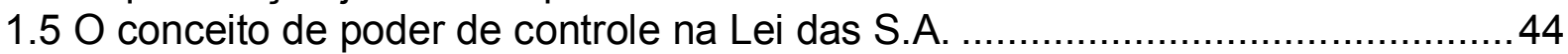

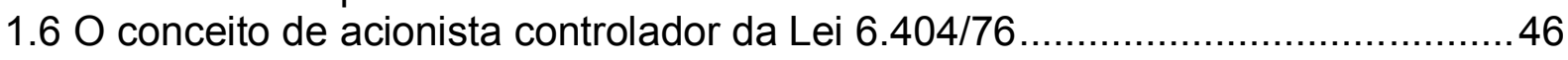

$1.7 \mathrm{O}$ caráter institucional disposto no parágrafo único do art.116 ..........................50

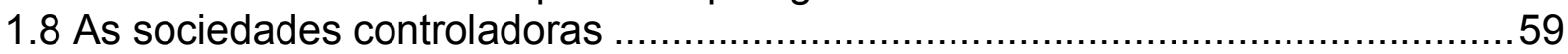

\section{CAPÍTULO 2 DO ABUSO DO PODER DE CONTROLE}

2.1 O conceito de abuso do poder de controle 62

$2.2 \mathrm{O}$ tratamento do abuso de poder de controle na Lei das S.A...........................65

2.3 Modalidades recorrentes de abuso de poder de controle................................73

2.3.1 Autofinanciamento da companhia e retenção de dividendos ..........................74

2.3.2 Remuneração elevada aos administradores com desvio de finalidade ............76

2.3.3 Adoção de políticas ou de decisões que não tenham por fim o interesse

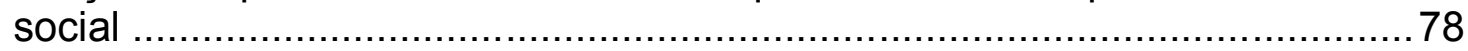

2.3.4 Abusos em detrimento dos diretores da companhia .................................. 89

2.3.5 Aumento de capital social com escopo de prejudicar a minoria acionária.........91

2.3.6 Abuso de poder na alienação do controle acionário.....................................93

2.3.7 O abuso no direito de voto do controlador .................................................93

2.3.8 O controlador que atua como insider trading ............................................... 97

\section{CAPÍTULO 3 FORMAS DE COIBIR O ABUSO DO PODER DE CONTROLE}

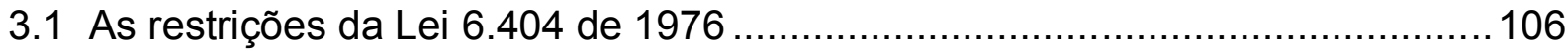

3.2 Os deveres fiduciários impostos ao controlador ......................................... 106

3.3. O aumento de garantias aos acionistas minoritários ...................................116

3.4. As ações possíveis contra o abuso do controlador .....................................126

3.4.1 A legitimidade para intentar as ações de responsabilidade........................... 129 
3.4.2 A restrição ao voto em conflito de interesses ............................................ 134

3.4.3 O acordo de acionistas como meio de defesa.........................................143

3.5 A realidade do Poder Judiciário e a migração para a arbitragem ..................... 145

3.6 O dualismo regulatório e a atuação da CVM .............................................. 150

3.6.1 A eficiência dos instrumentos sancionatórios utilizados pela CVM ................167

3.7 A discussão acerca do enforcement em relação a grandes casos de abuso de poder de controle envolvendo corrupção e o dano ao erário público .......................175

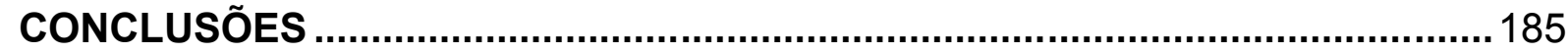

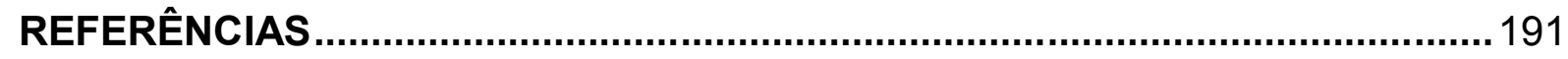




\section{RESUMO}

CUNHA, Lucas Marsili da. Formas de coibir o abuso do poder de controle nas sociedades anônimas. 2018. 221 f. Dissertação (Mestrado) - Faculdade de Direito, Universidade de São Paulo, São Paulo.

A inserção da figura do acionista controlador na reforma legislativa de 1976 teve como escopo o desenvolvimento do mercado de capitais ao acrescer a imposição explícita de poderes-deveres àquele ou àqueles que exercem o poder efetivo de direcionar os rumos das companhias. Todavia, mesmo após o advento da Lei $6.404 / 1976$, verificaram-se diversos casos de abuso do poder de controle, que trazem prejuízo não só para acionistas investidores, mas também para a sociedade. O presente trabalho tratará sobre o fenômeno do poder de controle e abordará os casos mais recorrentes em que ocorrem esses abusos. E, depois dessa análise, será feita uma avaliação se as formas de coibir o abuso do poder de controle previstas na Lei Societária brasileira são de fato eficientes.

Palavras-chave: Direito Societário. Lei 6.404/1976. Abuso de Poder de Controle. 


\begin{abstract}
CUNHA, Lucas Marsili da. Ways of curbing the abuse of power of control in corporations. 2018. 221 p. Thesis (Master's Degree) - Faculty of Law, University of São Paulo, São Paulo.

The insertion of the figure of the controlling shareholder in the 1976 reform of corporate legislation aimed at the development of the capital market by adding the explicit imposition of powers-duties to the one or those who exercise the effective power to rule the direction of the companies. However, even after de Law 6.404/1976 there have been several cases of abuse of control, which are detrimental not only to investor shareholders but also to society. The present work will study the phenomenon of the power of control. It will also address the most recurring cases in which such abuses occur. And after this analysis will evaluate if the ways to curb the abuse of control power provided by the Brazilian Corporate Law are effective to curb this abuses being practiced.
\end{abstract}

Keywords: Corporate Law. Law 6.404/1976. Abuse of the power of control. 


\section{INTRODUÇÃO}

As sociedades anônimas são sem dúvida uma das maiores invenções reguladas pelo Direito no escopo de agregar os recursos e os meios de produção necessários para a realização de grandes empreendimentos. Sua importância no desenvolvimento tecnológico industrial e até urbano da sociedade é inegável.

Esse desenvolvimento potencializa-se, em especial, após a evolução do mercado de capitais ligado a essas sociedades. Todavia, tamanha concentração de recursos e de poder possui grande capilaridade no tocante às demais relações econômicas e sociais, especialmente diante da globalização que se acentuou nos últimos 30 anos.

Portanto, quando ocorre algum tipo de disfunção no mercado de capitais, como se deu na crise dos títulos subprime (também chamados de "derivativos tóxicos") de $2007 / 2008$, os resultados negativos podem afetar drasticamente a economia mundial. ${ }^{1}$ Existem companhias, ainda que em menor proporção aos eventos relacionados à crise mencionada, que exercem larga influência, sendo capazes de produzir externalidades negativas e positivas em grande escala.

A título de exemplo, pode-se destacar o impacto gerado por um produto de uma grande companhia: a ferramenta de pesquisa da Google Inc, que possui a capacidade de direcionar uma quantidade maciça de informação ao mundo todo, escolhendo, v.g., que produto ou empresa será vista primeiro e até mesmo aqueles que serão omitidos. Assim, constata-se que a influência dessa companhia sobre os consumidores do mundo inteiro é imensa. ${ }^{2}$

Em função desse poder que determinadas companhias concentram em si, surge a primeira inquietação que motivou esta pesquisa: quem tem o poder sobre

\footnotetext{
${ }^{1}$ Sobre o mercado de derivativos cf. SOUZA JUNIOR, Francisco Satiro de. Derivativos de bolsa. In: KUYVEN, Luiz Fernando Martins (Coord.). Temas essenciais de direito empresarial: estudos em homenagem a Modesto Carvalhosa. São Paulo: Saraiva, 2012. p. 589-606. Sobre a crise de derivativos tóxicos cf. STOUT, Lynn A. How Deregulating Derivatives Led to Disaster, and Why ReRegulating Them can Prevent Another. Lombard Street, v. 1, n. 7 July, 10, 2009; UCLA School of Law, Law-Econ Research Paper n. 09-13. Disponível em: <https://ssrn.com/abstract=1432654>. Acesso em: 28 nov. 2017, e também cf. WHALEN, R. Christopher. The subprime crises - cause effects and consequences. Disponível em: <http://ssrn.com/abstract=1113888>. Acesso em: 2 dez. 2017.

${ }_{2}^{2}$ Importante mencionar também a influência da plataforma Youtube na última década, adquirida pela Google Inc. em 2006.
} 
essas grandes companhias? Essa pessoa ou grupo de pessoas (sejam físicas ou jurídicas) investiram na companhia um valor proporcional a esse poder que detêm? No Brasil, qual é o tratamento dado aos acionistas controladores? Os detentores dessa condição se submetem a um regime de deveres efetivamente proporcional aos poderes à sua disposição? Existem mecanismos eficientes que coíbam as situações em que ocorre o abuso desse poder?

Os estudos realizados por Adolf Augustus Berle Jr. e Gardiner Coit Means, na obra The Modern Corporation and Private Property, ${ }^{3}$ demonstram de forma sólida o fenômeno da separação entre a propriedade e o capital. ${ }^{4}$ Em suas pesquisas, que serão abordadas no decorrer deste trabalho, constatou-se que, quanto maior o volume do capital disperso em ações, mais ampla se denotava a separação entre a propriedade desse capital e o controle sobre ele. Esses estudiosos identificaram uma independência entre os conceitos de "controle", "propriedade" e "administração".

Verificou-se, assim, que o poder dentro das companhias ao longo do desenvolvimento do mercado de capitais foi gradativamente se concentrando nas mãos de terceiros, e não dos próprios acionistas que nelas investiram seu capital. Nos Estados Unidos esse poder deslocou-se ao longo do desenvolvimento daquele país para os administradores.

No Brasil, onde o mercado de capitais era incipiente, após algumas tentativas frustradas em relação ao seu desenvolvimento, o Estado optou por estabelecer uma nova legislação regulando as sociedades por ações, que conceituou e deu tratamento específico à figura do acionista controlador.

A Lei 6.404/1976 pautou-se na realidade societária brasileira, em que o capital se encontrava (e, em larga medida, ainda se encontra) altamente concentrado para abarcar a figura do acionista que possui o poder efetivo, fixandoIhe poderes-deveres.

\footnotetext{
${ }^{3}$ BERLE, Adolf Augustus; MEANS, Gardiner C. The Modern Corporation \& Private Property. New introduction by Murray Weindenbaum \& Mark Jensen. New York: Ed. Revista, 1967.

${ }^{4}$ Fábio Konder Comparato destaca que Karl Marx anteviu esse fenômeno em sua obra, conforme trecho a seguir: "A produção capitalista chegou a um ponto em que o trabalho de direção, completamente separado da propriedade do capital, é por todos admitido, de tal arte que doravante o capitalista não tem mais necessidade de exercer pessoalmente esta função. Um maestro não precisa de modo algum ser proprietário dos instrumentos da orquestra que dirige, nem lhe compete tratar do salário dos seus músicos" (MARX, Karl. Das Kapital, Kritik des politischen Ökonomie. Berlim: J. H. Dietz Nachfolger, 1929. v. 3, I apud COMPARATO, Fábio Konder. Aspectos jurídicos da macroempresa. São Paulo: RT, 1970. p. 71-72).
} 
Referida norma delineou-se de forma a projetar inúmeras situações ${ }^{5}$ que ainda não faziam parte do mercado de capitais brasileiro. Portanto, além de ser muito coesa, encontrava-se muito à frente do seu tempo no período de sua promulgação.

Outrossim, o escopo da Lei foi além e estabeleceu um rol de condutas que exemplificavam ações abusivas do acionista controlador, preceituando o cabimento de reparação por danos decorrentes.

A despeito disso, depois de mais de quarenta anos da legislação em vigor, ainda se verificam de forma recorrente situações de abuso de poder por parte do acionista controlador, por exemplo, no caso das Empresas " $X$ " de Eike Batista, ou mais recentemente no escândalo envolvendo a companhia JBS Friboi.

Nesse contexto, o presente trabalho almeja examinar se o ferramental contido na Lei de Sociedade por Ações (Lei das S.A.), utilizado desde 1976, e as reformas posteriores se mostram suficientes para coibir as ocorrências de abuso de poder de controle nas companhias de capital aberto brasileiras.

Essa investigação será realizada por meio da abordagem crítica, com a aplicação do método dialético (analisando as diferentes posições da literatura jurídica em destaque acerca do tema).

Nesse sentido, o estudo será dividido em três partes. O primeiro capítulo vai abordar o conceito e a natureza jurídica do poder de controle.

Para a realização dessa verificação, previamente se mostram necessárias a análise do contexto histórico do Brasil anterior à elaboração da Lei 6.404/1976, as motivações empregadas no curso do desenvolvimento do projeto e as expectativas de seus subscritores Alfredo Lamy Filho e José Luiz Bulhões Pedreira, particularmente no que tange à inclusão da figura do controlador.

\footnotetext{
${ }^{5}$ Esses atributos são assinalados pela maioria da doutrina, como é o caso de Nelson Eizirik: "Com efeito, mediante a promulgação da Lei $n .^{\circ}$ 6.404/1976, novos e importantes conceitos foram introduzidos no direito societário pátrio, promovendo um salto qualitativo nas práticas empresariais. Ademais, a Lei das S.A., ao adaptar ao nosso contexto institutos já consagrados em países com economias mais desenvolvidas, promoveu um alinhamento de nossa legislação societária com a dos sistemas jurídicos dos Estados Unidos e de países europeus que haviam, pouco antes, empreendido importantes reformas em suas leis sobre sociedades anônimas. Com a promulgação da Lei n. ${ }^{\circ}$ 6.404/1976, institucionalizou-se um sistema de disclousure para as companhias abertas, com auditoria externa obrigatória; normas de prevenção e repressão ao insider trading foram criadas, novos valores mobiliários foram introduzidos em nossa prática societária, bem como antigos foram atualizados (como é o caso das debentures), de modo a aumentar o leque de alternativas para a captação de recursos por parte das companhias no mercado; disciplinou-se a figura do controlador, novas responsabilidades foram atribuídas ao administradores das companhias etc." (EIZIRIK, Nelson. Reforma das S.A. e do mercado de capitais. 2. ed. Rio de Janeiro: Renovar, 1998. p. 3-4).
} 
Em seguida, serão tratados o conceito de poder de controle, as posições doutrinárias acerca desse instituto, bem como as diversas classificações sobre o controle.

Será ainda abordado o tratamento dado ao poder de controle na Lei das S.A. Em outras palavras, o modo como se regula esse instituto por meio da figura do acionista controlador nos termos preceituados no art. 116. Será examinada de maneira minuciosa a redação desse artigo em relação às exigências impostas para o exercício desse poder, bem como dos deveres fiduciários impostos ao acionista controlador no parágrafo único do art. 116. Também será analisado o caráter institucionalista que atribuiu ao acionista controlador deveres que se estendem para além daqueles com a companhia, abarcando os demais acionistas, os stakeholders e a comunidade em que a empresa atua.

Nesse capítulo se fará, ainda, um exame da questão do poder do controle, sob o ponto de vista das sociedades controladoras.

No segundo capítulo, analisar-se-á o abuso de poder de controle segundo a doutrina: seu conceito e as perspectivas acerca dos elementos caracterizados da situação abusiva.

Em seguida, será abordado o tratamento do abuso de poder do acionista controlador na Lei das S.A., procedendo-se a uma análise detalhada do art. 117 da Lei Societária e do rol de condutas contido no seu $\S 11^{\circ}$. Ademais, verificar-se-á o tratamento dado pela lei, ao abuso praticado pela sociedade controladora versado no art. 246.

Após o exame das posições doutrinária e legal a respeito do tema, far-se-á uma exposição, de caráter exemplificativo, das modalidades mais recorrentes de abuso do poder de controle, com o resumo de casos paradigmáticos sobre cada uma dessas modalidades e com o cotejo jurisprudencial.

No terceiro capítulo, serão verificados os instrumentos contidos na Lei 6.404/1976 para coibir o abuso de poder de controle. Neste estudo serão abarcados os deveres fiduciários impostos ao acionista controlador e ainda as contribuições trazidas pela Lei Societária e as reformas legislativas que a modificaram no sentido de aumentar as garantias em relação aos acionistas minoritários.

Ainda nesse capítulo serão examinadas as ações possíveis contra o abuso do controlador, englobando a restrição de voto no caso de conflito de interesses e a 
utilização do acordo de acionistas como meio de defesa por parte dos acionistas minoritários.

Outro ponto debatido será o problema da realidade do Poder Judiciário, tanto em relação à questão da morosidade na solução das demandas quanto à ausência de capacitação técnica para a realização da análise e julgamento de matérias tão específicas por parte do órgão estatal. Nessa esteira, será abordada a consequência desse problema, isto é, a migração dos casos ligados ao direito societário para a submissão ao julgamento pela via arbitral.

Ainda serão discutidas as normas administrativas impostas pela Comissão de Valores Mobiliários (CVM) e o dualismo regulatório adotado com o advento do Novo Mercado $^{6}$ e o sistema de autorregulação implementado para as companhias, que voluntariamente optaram por fazer parte desse segmento.

Por fim, serão discutidas as normas administrativas impostas CVM, sua pertinência e eficácia no que concerne a coibir abusos praticados pelos acionistas controladores no mercado de capitais.

Após o exame de todas essas questões, serão expostas as conclusões sobre a eficiência ou não de Lei Societária e dos demais instrumentos, tratados no presente trabalho, para coibir os abusos por parte dos controladores trazendo reflexões acerca dos resultados.

Essas conclusões não têm a pretensão de trazer soluções definitivas para os problemas examinados, mas visam fomentar o debate e a reflexão de pontos relevantes ligados ao problema do abuso do poder de controle, contribuindo assim para o estudo desse tema que assume grande relevância tanto no nosso país como no cenário internacional.

\footnotetext{
${ }^{6}$ Segundo Eduardo Secchi Munhoz, o Novo Mercado trouxe evolução inegável em matéria de governança corporativa e estimulou de forma inequívoca o desenvolvimento do Mercado de Capitais. Para ele: "[...] Exemplo de autorregulação bem-sucedida, o Novo Mercado, ao adotar regras especiais de governança corporativa, especialmente o princípio de que cada ação corresponde a um voto (one share - one vote), tornou-se arena principal da evolução do mercado de capitais brasileiro, atraindo um número expressivo de ofertas públicas primárias de ações (IPOS e follow ons)" (MUNHOZ, Eduardo Secchi. Aquisição de controle na sociedade anônima. São Paulo: Saraiva, 2013. p. 26).
} 


\section{CONCLUSÕES}

No presente trabalho, foi possível verificar que existia um interesse estatal no sentido de estimular o desenvolvimento do mercado de capitais brasileiro, proporcionando, assim, a captação de poupança popular para o desenvolvimento empresarial por outro mecanismo distinto do mercado financeiro.

Para alcançar esse objetivo, após o fracasso ocorrido no chamado boom bolsista de 1971, formou-se uma comissão para modernizar a nossa legislação societária glosando elementos do direito continental europeu com as práticas de mercado consagradas da legislação norte-americana e inglesa. $O$ fruto desse trabalho foi a Lei 6.404 , de 1976, que trouxe uma série de inovações e instituiu a figura do acionista controlador atribuindo-Ihe deveres fiduciários proporcionais aos poderes que detém.

Nesse sentido, vimos que Lamy e Bulhões, assim como os legisladores que debateram e chancelaram a Lei, fizeram a opção pela via da instituição da figura do controlador de modo a refletir a situação fática do País, de controle concentrado na grande maioria das companhias nos anos 1970.

Para parte da doutrina,${ }^{340}$ isso ocorreu porque não se entendia naquele momento histórico que houvesse maturidade em termos de desenvolvimento de mercado para se consagrar na legislação uma estrutura de capital difuso. Todavia, noutro passo, a Lei Societária, apesar de preconizar a figura do controlador, não previu óbices para o desenvolvimento de outras estruturas, como o desenvolvimento do Novo Mercado.

Além disso, a Lei 6.404/1976, segundo parte importante da doutrina examinada neste trabalho, possibilitou a aplicação do controle minoritário, por exemplo, ao prever que em segunda chamada para a realização da assembleia geral pode ocorrer a deliberação com qualquer quórum (art. 125).

No tocante às classificações do poder de controle, verificou-se que, apesar de um intenso debate doutrinário sobre a possibilidade de se conceituar o poder de controle, consolidou-se na doutrina nacional a posição de Comparato, no sentido de que o controle se define pelo exercício de um poder de fato, que pode ser realizado

\footnotetext{
${ }^{340}$ Cf. MUNHOZ, Eduardo Secchi. Aquisição de controle na sociedade anônima. São Paulo: Saraiva, 2013. p. 54-55 e 93-94.
} 
por meio dos instrumentos societários (controle interno) ou por meio de uma influência desvinculada do exercício de direitos dos acionistas (controle externo).

Nessa esteira, também se aferiu que a maioria da doutrina classificou as manifestações do controle da seguinte forma: (i) controle totalitário; (ii) controle majoritário; (iii) controle minoritário; e (iv) controle gerencial.

Como visto, no Brasil, em função da manutenção da concentração de capital, a maioria das companhias ainda é controlada por meio do voto majoritário. Entretanto, com o surgimento das listagens do Novo Mercado, houve um aumento exponencial de companhias nesses segmentos de listagem em que se verificam estruturas de controle mais diluído.

Constatou-se ainda que o abuso do poder de controle caracteriza-se pela atuação do acionista controlador em violação de seus deveres fiduciários, no escopo de se beneficiar de modo ilegal. Após o exame do conceito de abuso do poder de controle, foram evidenciados casos concretos pertinentes àquelas ações contidas no rol exemplificativo do $\S 1 .^{\circ}$ do art. 117 da Lei Societária.

No bojo desse exame, verificaram-se julgados em que ocorreram sanções compatíveis com o abuso praticado e outros em que a sanção ficou aquém do que seria proporcional ao dano causado, e ainda outros em que sequer houve sanção. Também foram analisados julgados em que se demonstrou uma dificuldade do Poder Judiciário de apreciar questões da matéria societária.

No Capítulo 3 realizou-se um exame dos artigos da Lei 6.404/1976, destacando alguns pontos de evolução em termos de proteção aos minoritários no tocante à legislação prévia. Nesse passo, também foram analisadas algumas das mudanças legislativas posteriores e seu impacto no que concerne a coibir abusos por parte do controlador.

Pode-se constatar na análise desses artigos em cotejo com a jurisprudência levantada que, tanto o Poder Judiciário, quanto a CVM, lastreiam suas condenações em casos de abuso de controle pautados em normas que, até o advento da Lei 6.404, sequer existiam de forma positivada. Apenas para exemplificar com um caso recente, destaca-se a condenação de Eike Batista na prática de insider trading, que não era tipificada na legislação anterior.

Também se observou que a Lei 10.303/2001 ampliou as garantias dos acionistas minoritários com relação ao acesso à informação e às possibilidades de representação (por exemplo, com a utilização do voto múltiplo). 
Evidentemente que existem pontos na Lei das S.A. que poderiam ser aperfeiçoados. Nesse sentido, destaca-se a previsão expressa para ação contra a sociedade controladora (art. 246) sem dispositivo correspondente à pessoa natural.

Nesse ponto, poderia haver procedimento semelhante ao do art. 246 dirigido a qualquer acionista controlador acrescido em um parágrafo ao final do art. 117, ou, ainda, com a inclusão de um parágrafo no próprio art. 246 esclarecendo que as disposições previstas naquele artigo aplicam-se às pessoas naturais que exercem o controle acionário.

Outro ponto que se mostra carecedor de uma definição é o art. 115 e o conflito (para parte de doutrina, ${ }^{341}$ apenas aparente) entre o caput e seus $\S \S 1 .^{\circ} \mathrm{e}$ $4 . \circ$.

Como demonstrado neste trabalho, a interpretação desse artigo traz divergência entre grandes juristas. $E$, sem entrar no mérito do debate, poderia 0 legislador se definir pelo conflito material, excluindo-se a hipótese de anulabilidade do $\S 44^{\circ}$ (interesse conflitante com o da companhia), ou criar duas regras explicitando em que casos o acionista não poderá votar e em que circunstância será admitido o voto, podendo ser anulado a posteriori, em hipóteses definidas em rol taxativo e objetivo.

No tocante à possibilidade de expropriação do controlador em casos de abuso envolvendo crimes de corrupção, considerando que o arcabouço legal atua de forma sistêmica na formatação de políticas públicas, e, ainda, que a prática de corrupção (prática de crime ao abusar do poder) se enquadra em uma espécie do gênero "abuso de poder de controle", parece mais adequado que seu tratamento seja dado pela Lei 12.846/2013 (conhecida como Lei Anticorrupção) pelo critério de especialidade.

A Lei 6.404 elenca no art. 117, $\S 1 .^{\circ}$, um rol exemplificativo de casos de abuso, sem prejuízo da aplicação concomitante da Lei Penal e de outras leis especiais. Assim sendo, parece mais adequada a solução preconizando a expropriação pela via da inclusão na Lei Anticorrupção de artigo nesse sentido.

No tocante à posição de Calixto Salomão Filho sobre da possibilidade de expropriação com base no art. 14 da Lei 12.846/2013, essa não se mostra a solução mais viável. Isso porque a previsão de desconsideração da pessoa jurídica não

${ }^{341}$ Vide item 3.4.2 supra. 
parece ser fundamento para a aplicação imediata da pena de expropriação por duas razões: (i) após a imposição da pena de multa, a execução se dará de modo menos gravoso ao réu, isto é, se ele possuir bens (distintos de suas ações) para pagar a multa não haveria justificativa para aplicar o regime da desconsideração - que possui caráter supletivo apenas nos casos em que a parte não possui patrimônio para saldar a dívida; (ii) como não existe previsão expressa acerca da expropriação, dependendo do ponto de vista, ela pode ser considerada pena mais grave (em especial sob o prisma subjetivo do controlador-réu) e, aplicando os princípios do direito penal, não se admitiria analogia para piorar a condição do réu.

Em suma, esse instituto deveria ser acrescido de forma específica à lei especial, ${ }^{342}$ evitando-se a arguição da violação de preceitos constitucionais pela tentativa de elastecer uma norma cujas previsões de sanção são distintas.

Nesse sentido, afigura-se muito adequada a sugestão de Ana Frazão ${ }^{343}$ para que a possibilidade de expropriação faça parte da negociação dos acordos de leniência ${ }^{344}$ (mediante alteração legal).

Outro ponto a se destacar é que a Lei $12.846 / 2013$ preceitua a "responsabilização administrativa e civil de pessoas jurídicas pela prática de atos contra a administração pública, nacional ou estrangeira", portanto restrita às pessoas jurídicas.

No texto legislativo, menciona-se uma única vez no $\S 2 .^{\circ}$ do art. $4 .^{\circ}$ que:

As sociedades controladoras, controladas, coligadas ou, no âmbito do respectivo contrato, as consorciadas serão solidariamente responsáveis pela prática dos atos previstos nesta Lei, restringindo-se tal responsabilidade à obrigação de pagamento de multa e reparação integral do dano causado.

Não destaca, porém, sanção específica adstrita à figura do controlador. Além disso, permanece o problema do controlador pessoa física, que é um reflexo da omissão da Lei Societária referida supra.

Ainda que a lei referida seja voltada para as pessoas jurídicas, deveria ocorrer uma construção normativa (ainda que pela via administrativa) no escopo de

\footnotetext{
342 Outro problema que se evita ao tratar dessa questão sem promover alterações na Lei Societária é a possibilidade de abuso de minoria, utilizando-se de instituto importante, de forma desnaturada (por exemplo, em casos em que sequer envolveria a prática de crimes).

${ }^{343}$ FRAZÃO, Ana. Os complexos impasses dos acordos de leniência. Valor Econômico, 9 ago. 2017. Disponível em: $<$ http://anafrazao.com.br/files/publicacoes/2017-08-09Os_complexos_impasses_dos_acordos_de_leniencia.jpg>. Acesso em: 10 dez. 2017. ${ }^{344}$ Vide item $3 . \overline{7}$ supra.
} 
possibilitar um acordo (com os devidos ajustes), para a exclusão da pessoa natural respondendo processos decorrentes de abuso do poder de controle, e a consequente preservação da companhia.

Para ser aplicada, portanto, uma sanção específica para o controlador relacionada à perda de sua propriedade acionária, parece imprescindível uma reforma legislativa e que de preferência já contemple a figura de pessoas físicas na condição de controlador.

No tocante à Lei 6.404/1976, em que pese o fato de ela poder ser aperfeiçoada, não se podem ignorar sua relevância e amplitude no sentido de permitir que outras regulações atuem em complemento a suas disposições.

Outro ponto a ser destacado é que não se deve examinar a eficácia ou ineficácia de um conjunto de normas isoladamente. A edição da Lei 6.404/1976 ocorreu em um período de grande instabilidade econômica que durou décadas.

A inflação que acometia o mercado nacional só se estabilizou no final da década de 1990 e a efetiva abertura de mercado para investimentos estrangeiros seguiu nesse mesmo passo. Esses fatores demonstram por que as condições para o desenvolvimento do Novo Mercado eram mais propícias (e culminaram com seu desenvolvimento a partir do ano de 2003).

Ainda que existam alguns pontos na Lei das S.A. que mereçam reparo, qualquer mudança radical pode trazer mais problemas do que soluções. Até porque, como mostrou o presente trabalho, os órgãos de regulação, como a CVM e a própria Bolsa Brasil Balcão (B3), possuem regras supletivas para os casos específicos de abuso do poder de controle.

Referidas normas possuem uma maior maleabilidade no que tange às suas alterações, o que vai ao encontro do dinamismo exigido nesse mercado.

Existe um movimento dos responsáveis por essa fiscalização nesse sentido, que pode ser constatado pela edição do "Novo Regulamento", que entrará em vigor no ano de 2018, e ainda da Lei 13.506/2017, que alterou dispositivos da Lei 6.385, aumentando a possibilidade de sanções a serem impostas e estendendo a tipificação relativa ao delito de insider trading para terceiros envolvidos na conduta delituosa.

A atenção da CVM no sentido de implementar maior rigidez nessas normas em casos específicos e de acentuar as demais medidas para promover a maior transparência possível parece ser a solução mais acertada para se construir um 
cenário de repressão a abusos, sem afetar drasticamente a estabilidade das relações no mercado de capitais.

Ainda que esse arcabouço normativo possa evoluir, sem nenhuma pretensão de esgotar esse debate, foi possível identificar uma nítida evolução nas formas de coibir o abuso de poder de controle após o advento da Lei 6.404/1976. E a impressão ao final desta investigação, tanto em relação à análise da jurisprudência como das medidas administrativas que estão sendo tomadas para inibir condutas abusivas, revelou-se mais positiva do que a expectativa contida no projeto de pesquisa inicial. 


\section{REFERÊNCIAS}

ADAMEK, Marcelo Vieira von. Responsabilidade civil dos administradores de S.A. e as ações correlatas. São Paulo: Saraiva, 2010.

. São Paulo: Saraiva, 2009.

AKERLOF, George A.; SHILLER, Robert J. Animal Spirits: How Human Psychology Drives the Economy, and Why It Matters for Global Capitalism. Princeton: Princeton University Press, 2009.

ARAGÃO, Leandro Santos de (Coord.). Direito societário: desafios atuais. São Paulo: Quartier Latin, 2009.

ARAGÃO, Paulo Cezar. A disciplina do acordo de acionistas na reforma da lei das sociedades por ações (Lei n. ${ }^{\circ} 10.303$, de 2001). In: LOBO, Jorge (Coord.). Reforma da Lei das Sociedades Anônimas: inovações e questões controvertidas da Lei n. ${ }^{\circ}$ 10.303, de 31.10.2001. Rio de Janeiro: Forense, 2002. p. 373.

ASCARELLI, Tullio. Problemas das Sociedades Anônimas e direito comparado. São Paulo: Saraiva, 1999.

ASQUINI, Alberto. Perfis da empresa. Tradução de Fábio Konder Comparato. Revista de Direito Mercantil, Industrial, Econômico e Financeiro, São Paulo, n. 104, p. 108-126, out.-dez. 1996.

ASSI, Marcos. Grandes fraudes da história: o caso Enron. Disponível em: <http://www.marcosassi.com.br/grandes-fraudes-da-historia-o-caso-enron>. Acesso em: $1 .^{\circ}$ jul. 2016.

ASSIS, Araken de. Cumprimento da sentença. Rio de Janeiro: Forense, 2006.

AZEVEDO, Luís André Negrelli de Moura. A oferta pública para aquisição de controle sob a perspectiva da companhia ofertante. In: CASTRO, Rodrigo R. 
Monteiro de; ARAGÃO, Leandro Santos de (Coord.). Direito societário: desafios atuais. São Paulo: Quartier Latin, 2009.

AXELROD, Robert M. The evolution of cooperation. New York: Basic Books, 2006.

BARBI FILHO, Celso. Acordo de acionistas. Belo Horizonte: Del Rey, 1993.

BARBOSA, Henrique Cunha. A exclusão do acionista controlador nas sociedades anônimas. Rio de Janeiro, Elsevier, Campus, 2009.

. Responsabilidade de controladores e administradores: o "Caso Sadia" numa incursão "guerreiriana" para além do dever de diligência e da ação social. In: Rodrigo R. Monteiro de Castro; Walfrido Jorge Warde Jr.; Carolina Dias Tavares Guerreiro. (Org.). Direito empresarial e outros estudos de direito em homenagem ao professor José Alexandre Tavares Guerreiro. São Paulo: Quartier Latin, 2013.

BARRA, Paula. Vale diz ser "mera acionista" da Samarco e não é responsável por acidente em MG. Infomoney. Disponível em: <http://www.infomoney.com.br/vale/noticia/4397648/vale-diz-ser-mera-acionistasamarco-nao-responsavel-por-acidente>. Acesso em: 14 nov. 2015.

BARRETO, Celso de Albuquerque. Acordo de acionistas. Rio de Janeiro: Forense, 1982.

BECHUCK, Lucian Arye. A rent-protection theory of corporate ownership and control. Working Paper, Cambridge, n. 7203, 1999.

. The myth of the shareholder franchise. Virginia Law Review, v. 93, p. 675, 2007.

et al. Pay without performance: overview of the issues. Journal of Corporation Law, v. 30, p. 647, 2005. 
et al. The costs of entrenched boards. Journal of Financial Economics, v. 78, p. 409, 2005.

; ROE, Mark J. A Theory of Path Dependence in Corporate Ownership and Governance. Stanford Law Review, v. 52, p. 127-170, Oct. 1, 1999; Columbia Law School, Center for Studies in Law \& Economics Paper, n. 131, Nov. 1999. Disponível em: <https://ssrn.com/abstract=202748>. Acesso em: 10 out. 2017.

BERLE, Adolf Augustus. For whom corporate managers are trustees: a note. Harvard Law Review, v. 45, p. 1365, 1932.

. The 20th Century Capitalist Revolution. New York: Harcourt, Brace and Co, 1954.

; MEANS, Gardiner C. A moderna sociedade anônima e a propriedade privada. Tradução de Dinah de Abreu Azevedo. São Paulo: Abril Cultural, 1984.

—_ _ _ _ _ _ Tradução de Dinah de Abreu Azevedo. São Paulo: Nova Cultural, 1988.

; Murray Weindenbaum \& Mark Jensen. New York: Ed. Revista, 1967.

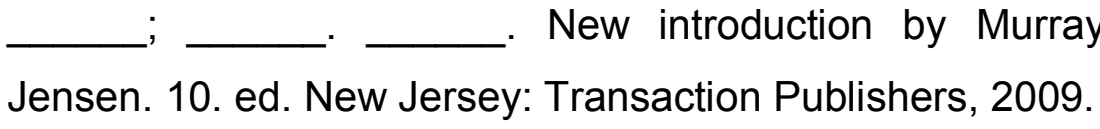

BERTOLDI, Marcelo Marco. Acordo de acionistas. São Paulo: RT, 2006.

. O poder de controle na Sociedade Anônima: alguns aspectos. Revista de Direito Mercantil, n. 118, p. 62-76, abr.-jun. 2000.

; KRAAKMAN, Reinier. Delaware's takeover law: the uncertain search for hidden value. Chicago: Northwestern University Law Review, 2002. 
BLOK, Marcella. Business Judgment Rule: a responsabilidade dos administradores das Sociedades Anônimas. Revista de Direito Bancário e do Mercado de Capitais, São Paulo, ano 12, n. 46, out.-dez. 2009.

- Conflito de interesses nas Sociedades Anônimas: critério de apuração formal ou substancial? Revista de Direito Mercantil, Industrial e Econômico, São Paulo, v. 153/154, 2011.

BM\&FBOVESPA.

Disponível em:

$<$ http://www.bmfbovespa.com.br/lumis/portal/file/fileDownload.jsp?fileld=8AA8D0975 F0E0FCA015F2B4AB2447BB2>. Acesso em: 20. nov. 2017.

BOBBIO, Norberto. O futuro da democracia. Rio de Janeiro: Paz e Terra, 1986.

BOITEAUX, Fernando. Responsabilidade civil do acionista controlador e da sociedade controladora. Rio de Janeiro: Forense, 1998.

BORBA, José Edwaldo Tavares. Direito societário. 8. ed. Rio de Janeiro: Renovar, 2003.

9. ed. Rio de Janeiro: Renovar, 2004.

BORK, Robert H. The antitrust paradox a policy at war with itself. New York: Free Press, 1993.

BOTELHO DE MESQUITA, José Ignácio. Execução específica de direito de preferência originado de acordo de acionistas. In: ADAMEK, Marcelo Vieira von (Coord.). Temas de direito societário e empresarial contemporâneos. Liber amicorum. Prof. Erasmo Valladão Azevedo e Novaes França. São Paulo: Malheiros, 2011.

BRADSHAW, Peter. Inside Job: how bankers caused the financial crisis. The Guardian. Disponível em: <https://www.theguardian.com/film/2011/feb/17/inside-jobfinancial-crisis-bankers-verdicts>. Acesso em: 12 fev. 2016. 
BRASIL. Lei n. ${ }^{\circ} 6.404,15$ dez. 1976. Dispõe sobre as sociedades por ações.

. Lei n. ${ }^{\circ}$ 9.307, 23 set. 1996. Dispõe sobre a arbitragem.

. Lei n. ${ }^{\circ}$ 10.303, 31 out. 2001. Altera e acrescenta dispositivos na Lei n. ${ }^{\circ}$ 6.404, de 15 de dezembro de 1976, que dispõe sobre as Sociedades por Ações, e na Lei ${ }^{\circ}{ }^{\circ} 6.385$, de 7 de dezembro de 1976, que dispõe sobre o mercado de valores mobiliários e cria a Comissão de Valores Mobiliários.

. Lei n. ${ }^{0} 11.101,9$ fev. 2005. Regula a recuperação judicial, a extrajudicial e a falência do empresário e da sociedade empresária.

. Lei n. ${ }^{\circ}$ 11.232, 22 dez. 2005. Altera a Lei n. ${ }^{\circ}$ 5.869, de 11 de janeiro de 1973. Código de Processo Civil, para estabelecer a fase de cumprimento das sentenças no processo de conhecimento e revogar dispositivos relativos à execução fundada em título judicial, e dá outras providências.

. Lei n. ${ }^{\circ}$ 5.869, 11 jan. 1973. Institui o Código de Processo Civil (revogado pela Lei n. $\left.{ }^{0} 13.105 / 2015\right)$.

. Lei n. ${ }^{\circ}$ 15.105/2015, 16 mar. 2015. Institui o novo Código de Processo Civil.

. Lei n. ${ }^{\circ} 12.846 / 2013,1 .^{\circ}$ ago. 2013. Institui o novo Código de Processo Civil. Dispõe sobre a responsabilização administrativa e civil de pessoas jurídicas pela prática de atos contra a administração pública, nacional ou estrangeira, e dá outras providências.

. Lei n. ${ }^{0} 13.506 / 2016,13$ nov. 2017. Dispõe sobre o processo administrativo sancionador na esfera de atuação do Banco Central do Brasil e da Comissão de Valores Mobiliários; altera a Lei n. ${ }^{\circ}$ 6.385, de 7 de dezembro de 1976, a Lei n. ${ }^{\circ}$ 4.131, de 3 de setembro de 1962, a Lei n. ${ }^{\circ} 4.829$, de 5 de novembro de 1965, a Lei n. ${ }^{\circ} 6.024$, de 13 de março de 1974 , a Lei n. ${ }^{\circ}$ 7.492, de 16 de junho de 1986, a Lei n. ${ }^{\circ}$ 9.069, de 29 de junho de 1995, a Lei n. ${ }^{\circ} 9.613$, de 3 de março de 1998, a Lei n. ${ }^{\circ}$ 10.214, de 27 de março de 2001, a Lei n. ${ }^{\circ} 11.371$, de 28 de novembro de 2006, a Lei 
n. ${ }^{\circ} 11.795$, de 8 de outubro de 2008, a Lei n. 12.810 , de 15 de maio de 2013, a Lei n. ${ }^{\circ} 12.865$, de 9 de outubro de 2013, a Lei n. 4.595 , de 31 de dezembro de 1964, o Decreto n. ${ }^{\circ} 23.258$, de 19 de outubro de 1933, o Decreto-lei n. ${ }^{\circ}$ 9.025, de 27 de fevereiro de 1946, e a Medida Provisória n. ${ }^{\circ} 2.224$, de 4 de setembro de 2001; revoga o Decreto-lei n. ${ }^{\circ} 448$, de 3 de fevereiro de 1969, e dispositivos da Lei $n .^{\circ}$ 9.447, de 14 de março de 1997, da Lei n. ${ }^{\circ}$ 4.380, de 21 de agosto de 1964, da Lei n. ${ }^{\circ} 4.728$, de 14 de julho de 1965, e da Lei n. 9.873 , de 23 de novembro de 1999; e dá outras providências.

. Comissão de Valores Mobiliários - CVM. Inquérito Administrativo n. ${ }^{\circ}$ 30/98. Acesso à informação. Disponível em:

<http://www.cvm.gov.br/export/sites/cvm/sancionadores/sancionador/anexos/2001/2 0010705_PAS_3098.pdf>. Acesso em: 24 nov. 2016.

. Comissão de Valores Mobiliários - CVM. Inquérito Administrativo CVM n. ${ }^{\circ}$ TA/RJ2001/4977. Disponível em: <http://www.cvm.gov.br/export/sites/cvm/sancionadores/sancionador/anexos/2001/2 0011219_PAS_RJ20014977.pdf>. Acesso em: 15 mar. 2017.

. Comissão de Valores Mobiliários - CVM. Inquérito Administrativo CVM n. ${ }^{\circ}$ TA/RJ2002/1153. Disponível em:

<http://www.cvm.gov.br/export/sites/cvm/sancionadores/sancionador/anexos/2002/2 0021106_PAS_RJ20021153.pdf>. Acesso em: 12 nov. 2016.

. Comissão de Valores Mobiliários - CVM. Instrução CVM n. ${ }^{3}$ 323. Disponível em:

<http://www.cvm.gov.br/export/sites/cvm/legislacao/instrucoes/anexos/300/inst323.p df>. Acesso em: 15 jul. 2017.

Comissão de Valores Mobiliários - CVM. Instrução Normativa n. ${ }^{\circ} 358$. Disponível em: <http://www.cvm.gov.br/legislacao/inst/inst358.html>. Acesso em: 30 ago. 2015. 
. Comissão de Valores Mobiliários - CVM. Instrução Normativa n. ${ }^{\circ}$ 552/2014. Altera e acrescenta dispositivos à Instrução 480/09 e altera dispositivos das Instruções 358/02 e 481/09. Publicada no DOU de 13.10.14. Disponível em: <http://www.cvm.gov.br/legislacao/inst/inst552.html>. Acesso em: 10 nov. 2015.

. Comissão de Valores Mobiliários - CVM. Regulamentos. Instrução CVM n. ${ }^{\circ}$ 452. Disponível em: <http://www.cvm.gov.br/legislacao/instrucoes/inst452.html>. Acesso em: 28 out. 2017.

. Comissão de Valores Mobiliários - CVM. Instrução n. ${ }^{\circ}$ 586/2017. Disponível em: <http://www.cvm.gov.br/legislacao/instrucoes/inst586.html>. Acesso em: 30 nov. 2017

. Comissão de Valores Mobiliários - CVM. PAS 126/2015. Acesso à informação. Disponível

em: <http://www.cvm.gov.br/sancionadores/sancionador/2005/20051206_RJ200111949.h tml>. Acesso em: 1. ${ }^{\circ}$ jun. 2016.

Comissão de Valores Mobiliários - CVM. PAS RJ 13172/2013. Acesso à informação. Disponível em:

<http://www.cvm.gov.br/export/sites/cvm/sancionadores/sancionador/anexos/2017/R J201313172_OSX_Brasil.pdf>. Acesso em: 10 maio 2017.

. Comissão de Valores Mobiliários - CVM. PAS 03/2002. Disponível em: <http://www.cvm.gov.br/export/sites/cvm/sancionadores/sancionador/anexos/2004/2 0040212_PAS_0302.pdf >. Acesso em: 16 dez. 2017.

. Comissão de Valores Mobiliários - CVM. PAS 04/1999. Acesso à informação. Disponível em: <http://www.cvm.gov.br/export/sites/cvm/sancionadores/sancionador/anexos/2002/2 0020417_PAS_0499.pdf>. Acesso em: 7 jun. 2017. 
Comissão de Valores Mobiliários - CVM PAS 07/2003. Disponível em: <http://www.cvm.gov.br/export/sites/cvm/sancionadores/anexos/sancionador/2007/2 0070704_PAS_0703.pdf>. Acesso em: 29 jun. 2016.

. Comissão de Valores Mobiliários - CVM. PAS CVM 18/2008. Disponível em:

<http://www.cvm.gov.br/export/sites/cvm/sancionadores/sancionador/anexos/2010/2 0101214_PAS_1808.pdf>. Acesso em: 15 dez. 2017

. Comissão de Valores Mobiliários - CVM. PAS 24/2003. Disponível em: <http://www.cvm.gov.br/export/sites/cvm/sancionadores/sancionador/anexos/2005/2 0050609_PAS_2403.pdf>. Acesso em: 13. set. 2017.

. Comissão de Valores Mobiliários - CVM. PAS 0703.2007. Acesso à informação.

Disponível

em:

<http://www.cvm.gov.br/export/sites/cvm/sancionadores/sancionador/anexos/2007/2 0070704_PAS_0703.pdf>. Acesso em: 29 jun. 2015.

. Comissão de Valores Mobiliários - CVM. PAS 1106.2002. Acesso à informação.

Disponível

em:

<http://www.cvm.gov.br/sancionadores/sancionador/2002/20021106_RJ20021153.ht ml>. Acesso em: 29 jun. 2015.

. Comissão de Valores Mobiliários - CVM. PAS 7190-4. Acesso à informação. em: <http://www.cvm.gov.br/export/sites/cvm/decisoes/anexos/0007/7190-4.pdf>. Acesso em: 30 jul. 2015.

. Comissão de Valores Mobiliários - CVM. PAS RJ 2001/11949. Disponível em:

<http://www.cvm.gov.br/export/sites/cvm/sancionadores/anexos/sancionador/2005/2 0051206_PAS_RJ200111949.pdf>. Acesso em: 1. jul. 2016.

. Comissão de Valores Mobiliários - CVM. PAS RJ 2007/1996. 
Disponível

em:

<http://www.cvm.gov.br/export/sites/cvm/decisoes/anexos/0003/5443-0.pdf>. Acesso em: 18 nov. 2017.

. Comissão de Valores Mobiliários - CVM. PAS SP 2007/0118. Disponível em:

<http://www.cvm.gov.br/export/sites/cvm/sancionadores/sancionador/anexos/2008/2 0080226_PAS_SP20070118.pdf>.Acesso em: 20 maio 2017.

. Comissão de Valores Mobiliários - CVM. Processo CVM RJ 2009/5811.

Disponível

em:

<http://d1ao0r2iuz522v.cloudfront.net/5f4edc37eb4aad739f7bf41d349bd720.pdf>.

Acesso em: 10 jun. 2017.

. Comissão de Valores Imobiliários - CVM. Processo CVM RJ 2009/13179.

Disponível

em:

<http://www.cvm.gov.br/export/sites/cvm/decisoes/anexos/0007/7190-4.pdf>. Acesso em: 8 jan. 2017.

. Comissão de Valores Mobiliários - CVM. Resultado de julgamento. PAS

CVM RJ 2012/4062. Disponível em:

<http://www.cvm.gov.br/noticias/arquivos/2013/20131217-4.html>. Acesso em: 20 maio 2017.

. Supremo Tribunal Federal. ARE 971.036/SP. Rel. Min. Dias Toffoli. j. 16.06.2016. Disponível em: <stf.jus.br/>. Acesso em:16. out. 2017.

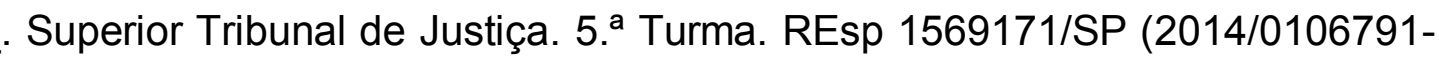
6). Min. Joel Ilan Paciornik. j. 16.02.2016. Disponível em: <https://ww2.stj.jus.br/processo/revista/documento/mediado/?componente=ITA\&seq uencial=1480454\&num_registro=201401067916\&data=20160225\&formato=PDF>. Acesso em: 12 mar. 2017. 
. Superior Tribunal de Justiça. REsp 556.265/RJ. Min. Barros Monteiro. DJ 13.02.2006, p. 803.

. Superior Tribunal de Justiça. 5. a Turma. RHC 505/SP. Recurso Ordinário em Habeas Corpus 1990/0000795-0. Rel. Min. Assis Toledo. j. 16.04.1990. Disponível em: <stj.jus.br/>. Acesso em: 14. jul. 2017.

. Superior Tribunal de Justiça. REsp 798264/SP (2005/0190864-1). Rel. Min. Carlos Alberto Menezes Direito. j. 06.02.2017. DJ 16.04.2007. Disponível em: <stj.jus.br/>. Acesso em: 15. abr. 2017.

- Tribunal de Justiça de São Paulo. Agravo de Instrumento 036258773.2009.8.26.0000 (990.09.362587-3). Agravante: Adriano Lima Ferreira. Agravado: Sadia S.A. Rel. Des. Enio Zuliani. j. 26.08.2010. Disponível em: <tjsp.jus.br/>. Acesso em: 14. jul. 2017.

- Tribunal de Justiça de São Paulo. 10. ${ }^{\text {a }}$ Câmara de Direito Privado. Apelação 9209787042009826 SP/9209787-04.2009.8.26.0000. Rel. Cesar Ciampolini. j. 30.10.2012. DJ 31.10.2012. Disponível em: <tjsp.jus.br/>. Acesso em: 15. abr. 2017.

. Tribunal Regional Federal da $1^{a}$ Região. Apelação Criminal 000382805.2006.4.01.3500/2006.35.00.003838-0/GO. Rel. Hilton Queiroz. j. 15.02.2005. Disponível em: <trf1.jus.br/>. Acesso em: 18. nov.2017.

BRINA, Osmar Corrêa-Lima. Regra do julgamento de negócios (business judgment rule). In: SILVA, Alexandre Couto. Direito societário: estudos sobre a Lei de Sociedade por Ações. São Paulo: Saraiva, 2013. p. 164. 
BULGARELLI, Waldirio. A proteção das minorias nas S.A. São Paulo: Pioneira, 1975.

A regulamentação jurídica do acordo de acionistas no Brasil. Revista de Direito Mercantil, Industrial, Econômico e Financeiro, São Paulo, v. 40, p. 80-92, out.-nov. 1980.

. Manual das Sociedades Anônimas. 11. ed. São Paulo: Atlas, 1999.

. Questões atuais de direito empresarial. São Paulo: Malheiros, 1995.

et al. Reforma da Lei das sociedades por ações. São Paulo: Pioneira, 1998.

. Regime jurídico de proteção às minorias nas S.A. Rio de Janeiro: Renovar, 1998.

BULHÕES PEDREIRA, José Luiz. Acordo de acionistas sobre controle de grupo de sociedades. Validade de estipulação de que os membros do conselho de administração de controladas devem votar em bloco segundo orientação definida pelo grupo controlador. Revista de Direito Bancário e do Mercado de Capitais, n. 15, p. 226.

CALÇAS, M. Q. P. A proteção do sócio minoritário na lei das sociedades anônimas brasileira. In: COELHO, Fábio Ulhoa; RIBEIRO, Maria de Fátima (Org.). Questões de direito societário em Portugal e no Brasil. Coimbra: Almedina, 2012. v. 1, p. 219-251.

CAMPINHO, Sérgio; PINTO, Mariana. Diretor estatutário x diretor empregado: o regime jurídico do diretor da sociedade anônima. Revista Semestral de Direito Empresarial, Rio de Janeiro, n. 4, jan.-jun. 2009.

CANTIDIANO, Luiz Leonardo. Direito societário e mercado de capitais. Rio de Janeiro: Renovar, 1996. 
CAPITAL ABERTO. Quanto custa uma infração, $1 .^{\circ}$ mar. 2014, republicada no setor Notícias portal do Insper. Disponível em: <https://www.insper.edu.br/noticias/quantocusta-uma-infracao/>. Acesso em: 4 abr. 2017.

CARVALHAL, André; LEAL, Ricardo P. C. Corporate Governance, Market Valuation and Dividend Policy in Brazil. Coppead Working Paper Series, n. 390, Nov. 2003. Disponível em: <https://ssrn.com/abstract=477302>. Acesso em: 12 jul. 2017.

CARVAlHOSA, Modesto Souza Barros. Acordo de acionistas. São Paulo: Saraiva, 1984.

. Acordo de acionistas: homenagem a Celso Barbi Filho. São Paulo: Saraiva, 2011.

. A nova Lei das Sociedades Anônimas: seu modelo econômico. 2. ed. Rio de Janeiro: Paz e Terra, 1977.

. Comentários à Lei das Sociedades Anônimas. 4. ed. São Paulo: Saraiva, 2009.

4. ed. São Paulo: Saraiva, 2011. v. 4, t. II.

. Comentários à Lei de Sociedades Anônimas: arts. 75 a 157. 5. ed. São Paulo: Saraiva, 2011. v. 2.

Considerações sobre a Lei Anticorrupção das Pessoas Jurídicas. Revista dos Tribunais, 2015.

- Vinculação dos administradores ao acordo de controle $\left(\S \S 8 .^{\circ}\right.$ e $9 .^{\circ}$ do artigo 118 da LSA. Sociedades anônimas e mercado de capitais: homenagem ao Prof. Osmar Brina Corrêa-Lima. Arnoldo Wald, Fernando Gonçalves, Moema Augusta Soares de Castro (Coord.); Bernardo Vianna Freitas, Mário Tavernard Martins de Carvalho (Org.); Adriano Augusto Teixeira Ferraz et al. São Paulo: Quartier Latin, 2011. 
; EIZIRIK, Nelson. A nova Lei das Sociedades Anônimas. São Paulo:

Saraiva, 2002.

CHAMPAUD, Claude. Le pouvoir de concentracion de societé por action. Paris: Sirey, 1962.

COELHO, Fábio Ulhoa. Curso de direito comercial. 3. ed. São Paulo: Saraiva, 2008.

. Curso de direito comercial. São Paulo: Saraiva, 2013.

. Profissão: minoritário. In: CASTRO, Rodrigo R. Monteiro de; ARAGÃO,

Leandro Santos de (Coord.). Sociedade anônima: 30 anos da Lei 6.404/76. São Paulo: Quartier Latin, 2007.

COFFEE JR., John C. What Caused Enron?: A Capsule Social and Economic History of the 1990's. Columbia Law and Economics Working Paper, n. 214. Disponível em: <https://ssrn.com/abstract=373581>. Acesso em 10 jan. 2017

. The Rise of Dispersed Ownership: The Role of Law in the Separation of Ownership and Control. The Center for Law and Economic Studies Working Paper, n. 182, jan. 2001.

COMPARATO, Fábio Konder. Acordo de acionistas e interpretação do art. 118 da Lei das S.A. Revista dos Tribunais, v. 527, p. 32, set. 1979.

. Aspectos jurídicos da macro-empresa. São Paulo: RT, 1970.

. Controle conjunto, abuso no exercício do voto acionário e alienação indireta de controle empresarial. São Paulo: Saraiva, 1990.

. Direito empresarial. São Paulo: Saraiva, 1983.

. Novos ensaios e pareceres de direito empresarial. Rio de Janeiro: Forense, 1981. 
. O direito e o avesso. Rumo à Justiça. São Paulo: Saraiva, 2010.

. O poder de controle na Sociedade Anônima. São Paulo: RT, 1977.

. O poder de controle na Sociedade Anônima. 3. ed. Rio de Janeiro: Forense, 1983.

; SALOMÃO FILHO, Calixto. O poder de controle na Sociedade Anônima. 5. ed. Rio de Janeiro: Forense, 2010.

6. ed. Rio de Janeiro: Forense, 2014.

CORRÊA, Douglas. Economia. Justiça extingue processo contra Eike Batista por prejuízos a acionistas da OGX. Portal EBC-Agência Brasil. Disponível em: $\quad$ <http://agenciabrasil.ebc.com.br/economia/noticia/2016-05/justica-extingueprocesso-contra-eike-batista-por-prejuizos-acionistas-da>. Acesso em: 9 jul. 2016.

COSTA, Carlos Celso Orcesi da. Controle Externo das Companhias. Revista de Direito Mercantil, 44/75.

CRAVEIRO, Mariana Conti. Contratos entre sócios: interpretação e direito societário. São Paulo: Quartier Latin, 2013.

CRISTO, Alessandro. Reforma do Judiciário. Projetos de gestão mudam funcionamento da Justiça. Consultor Jurídico. Disponível em: <http://www.conjur.com.br/2009-jul-11/projetos-gestao-seduzem-tribunais-mudamfuncionamento-justica>. Acesso em: 25 abr. 2015.

CVM. História do mercado de capitais no Brasil. Disponível em: <www.portaldoinvestidor.gov.br>. Acesso em: 30 set. 2014.

DALBERG, John Emerich Edward (Lord Acton). Letters of Lord Acton to Mary, Daughter of the Right Hon. W.E. Gladstone. 2. ed. London: Macmillan, 1913. 
DICIONÁRIO HOUAISS. Disponível em: <http://houaiss.uol.com.br/busca.jhtm>. Acesso em: 22 fev. 2016.

DINAMARCO, Cândido Rangel. Processo civil empresarial. 2. ed. São Paulo: Malheiros, 2014.

DODD, E. M. For whom are corporate managers trustees? Harvard Law Rev., n. 45, p. 1145-1163, 1932.

ECONOMIA. Arthur Andersen é indiciada no caso Enron. Portal BBC Brasil. Disponível em: $<$ http://www.bbc.com/portuguese/economia/020314_andersendi.shtml>. Acesso em: 23 maio 2015.

Com denúncias envolvendo companhias abertas, CVM quer endurecer punições. Portal Tribuna Paraná Online. Disponível em:

$<$ http://www.paranaonline.com.br/editoria/economia/news/853051/?noticia=COM+DE NUNCIAS+ENVOLVENDO+COMPANHIAS+ABERTAS+CVM+QUER+ENDURECER +PUNICOES>. Acesso em: 23 abr. 2015.

. Crise das empresas " $X$ " afeta imagem do Brasil, diz Mantega. Agência EFE reprodução Portal Revista Exame. Disponível em: <http://exame.abril.com.br/economia/noticias/crise-das-empresas-x-afeta-imagemdo-brasil-diz-mantega>. Acesso em: 4 out. 2015.

CVM abre novo processo contra Petrobras. Além da estatal, órgão regulador de mercado apura responsabilidades de ex-dirigentes sobre capitalização em 2010. Portal Estadão. Disponível em: $<$ http://economia.estadao.com.br/noticias/geral,cvm-abre-novo-processo-contrapetrobras,10000008706>. Acesso em: 3 jul. 2016.

. Portal Estadão. O escândalo Enron: saiba o que está acontecendo. Disponível em: <http://economia.estadao.com.br/noticias/geral,o-escandalo-daenron-saiba-o-que-esta-acontecendo,20020207p24521>. Acesso em: 9 dez. 2015. 
EIZIRIK, Nelson. Acordo de acionistas. Arquivamento na sede social. Vinculação dos administradores de sociedade controlada. Revista de Direito Mercantil, Econômico e Financeiro, São Paulo, v. 129, p. 45, 2003.

. A Lei das S.A. comentada: arts. 1. $^{\circ}$ a 120. São Paulo: Quartier Latin, 2011. v. 1.

A nova Lei das S.A. São Paulo: Saraiva, 2010.

- Aquisição de controle. Inexigibilidade de oferta pública. In: CASTRO, Rodrigo R. Monteiro de; ARAGÃO, Leandro Santos de (Coord.). Direito societário: desafios atuais. São Paulo: Quartier Latin, 2009.

. O mito do "controle gerencial": alguns dados empíricos. Revista de Direito Mercantil Industrial, Econômico e Financeiro, São Paulo, ano XXVI, n. 66, p. 103106, abr.-jun. 1987.

Reforma das S.A. e do mercado de capitais. 2. ed. Rio de Janeiro: Renovar, 1998.

. Temas de direito societário. São Paulo: Renovar, 2005.

; GAAL, Ariádna B.; PARENTE, Flávia; HENRIQUES, Marcus de Freitas. Mercado de capitais: regime jurídico. Rio de Janeiro: Renovar, 2008.

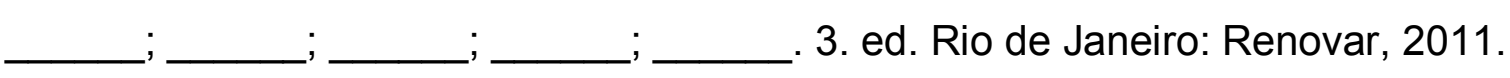

et al. O Comitê de Aquisições e Fusões: versão brasileira do takeover panel. In: KUYVEN. (Coord.). Temas essenciais de direito empresarial: estudos em homenagem a Modesto Carvalhosa. São Paulo: Saraiva, 2012.

EMPRESAS. Confesso que errei. Portal Valor Econômico Disponível em: <http://www.valor.com.br/empresas/3957516/confesso-que-errei>. Acesso em: 5 jul. 2016. 
FALK, Armin; SZECH, Nora. Morals and markets. Science, v. 340, p. 707 e ss., 10 maio 2013.

FAZZIO JR., Waldo. Manual de direito comercial. São Paulo: Atlas, 2000.

. 6. ed. São Paulo: Atlas, 2005.

FERREIRA, Waldemar. Sociedades comerciais irregulares. São Paulo: Editora Limitada, 1927.

FERRI, Giuseppe, Le società. Torino: UTET, 1971.

FINKELSTEIN, Maria Eugênia. Assimetria de informações no mercado de capitais. In: ROVAI, Armando Luiz; MURRAY NETO, Alberto (Coord.). As sociedades por ações na visão prática do advogado. São Paulo: Elsevier, 2010.

FLAKS, Luis Loria. A arbitragem na reforma da Lei das S.A. Revista de Direito Mercantil, Industrial, Econômico e Financeiro, São Paulo, n. 131, p. 117, 2003.

FONSECA, Priscila Maria Pereira Corrêa da. Suspensão de deliberações sociais. São Paulo: Saraiva, 1986.

FORGIONI, Paula Andrea. A evolução do direito comercial brasileiro. 2. ed. São Paulo: RT, 2012.

. Contratos empresariais: teoria geral e aplicação. 2. ed. São Paulo: RT, 2016.

. Os fundamentos do antitruste. 6. ed. São Paulo: RT, 2013.

FRANÇA, Erasmo Valladão Azevedo e Novaes. Conflitos de interesse nas Assembleias de S.A. São Paulo: Malheiros, 1993. 
. Conflito de interesses nas Assembleias de S.A. (e outros escritos sobre conflito de interesses). 2. ed. São Paulo: Malheiros, 2014.

(Coord.). Direito societário contemporâneo I. São Paulo: Quartier Latin, 2009. Obra coletiva.

. Invalidade das deliberações de assembléia das S.A. São Paulo: Malheiros, 1999.

FRANCO, Vera Helena de Mello; SZTAJN, R. Direito empresarial: sociedade anônima. Mercado de valores mobiliários. 2. ed. São Paulo: RT, 2009. v. 2.

FRAZÃO, Ana. Os complexos impasses dos acordos de leniência. Valor Econômico, 9 ago. 2017. Disponível em: <http://anafrazao.com.br/files/publicacoes/2017-08-09Os_complexos_impasses_dos_acordos_de_leniencia.jpg>. Acesso em: 10 dez. 2017.

FRONTINI, Paulo Salvador, Sociedade Anônima - Direito de retirada - Recesso de dissidente - Lei Lobão: um precedente judicial. Revista de Direito Mercantil, Industrial, Econômico e Financeiro, v. 86, p. 71-77, abr.-jun. 1982.

FURTADO, Celso. Formação econômica do Brasil. São Paulo: Companhia Editora Nacional, 2009.

GALGANO, Francesco. Diritto commerciale: le società. 15. ed. Bologna: Zanichelli, 2005.

GEVURTZ. The globalization of corporate law: the end of history or a never-ending story?. Washington Law Review, v. 86, n. 3, p. 475, 2011.

GILSON, Ronald J. Controlling Family Shareholders in Developing Countries: Anchoring Relational Exchange. Columbia Law and Economics Working Paper n. 311, Jan. 1, 2007; Stanford Law and Economics Olin Working Paper n. 333; ECGI Law Working Paper n. 79/2007; Rock Center for Corporate Governance at Stanford University Working Paper n. 10. Disponível em: <https://ssrn.com/abstract=957895>. Acesso em: 12 jul. 2017 
. Controlling shareholders and corporate governance: complicating the comparative taxonomy. Harvard Law Review, v. 119, p. 1642, 2005.

- Globalizing corporate governance: convergence of form or function. American Journal of Comparative Law, n. 49, p. 329, 2001.

; GORDON, Jeffrey N. Controlling Controlling Shareholders. Columbia Law and Economics Working Paper, n. 228, Jun. 2003; Stanford Law and Economics Olin Working Paper, n. 262. Disponível em: <http://dx.doi.org/10.2139/ssrn.41718>. Acesso em: 9 jul. 2017.

; HANSMANN, Henry; PARGENDLER, Mariana. Regulatory dualism as a development strategy: corporate reform in Brazil, the United States, and the European Union. Stanford Law Review, v. 63, p. 487, 2011.

; LEKVALL, Per; HANSEN, Jesper Lau; LØNFELDT, Carsten; AIRAKSINEN, Manne; BERGLUND, Tom; VON WEYMARN, Tom; KNUDSEN, Gudmund; NORVIK, Harald; SKOG, Rolf; SJÖMAN, Erik. The Nordic Corporate Governance Model, Dec. 1, 2014. Nordic \& European Company Law Working Paper n. 14-12. Disponível em: <https://ssrn.com/abstract=2534331>. Acesso em: 10 dez. 2017.

; SCHWARTZ, Alan. Corporate Control and Credible Commitment. Columbia Law and Economics Research Paper n. 436, Nov. 19, 2014; Stanford Law and Economics Olin Research Paper n. 438; Yale Law \& Economics Research Paper n. 461; ECGI - Law Working Paper n. 216. Disponível em: <https://ssrn.com/abstract=2182781>. Acesso em: 28 set. 2016.

GOMES, Carlos Jacques Vieira. Manual de direito empresarial. Brasília: Fortium, 2008.

GOOGLE INC. - 2004 Founders' IPO Letter “An Owner's Manual for Google's Shareholders". Disponível em: <https://abc.xyz/investor/founders-letters/2004/ipoletter.html>. Acesso em: 23 jul. 2017. 
GORGA, Érica. Changing the Paradigm of Stock Ownership: From Concentrated Towards Dispersed Ownership? Evidence from Brazil and Consequences for Emerging Countries. 3rd Annual Conference on Empirical Legal Studies Papers, Apr. 2008. Disponível em: <https://ssrn.com/abstract=1121037>. Acesso em: 10 jul. 2017.

. Corporate Control \& Governance after a Decade from "Novo Mercado": Changes in Ownership Structures and Shareholder Power in Brazil. Yale Law \& Economics Research Paper n. 502, Jul. 29, 2014. Disponível em: <https://ssrn.com/abstract=2473832>. Acesso em: 15 jul. 2017.

GUERREIRO, José Alexandre Tavares. Execução específica do acordo de acionistas. Revista de Direito Mercantil, Econômico e Financeiro, São Paulo, v. 41, p. 40 , p. $52-53$.

. Sobre a interpretação do objeto social. Revista de Direito Mercantil, Industrial, Econômico e Financeiro, São Paulo: RT, n. 54, p. 71-72, abr.-jun. 1984.

. Sociedade anônima: poder e dominação. Revista de Direito Mercantil, Industrial, Econômico e Financeiro, São Paulo, n. 53, p. 72-80, jan.-mar. 1984.

. Sociologia do poder na sociedade anônima. Revista de Direito Industrial, Econômico e Financeiro, v. 77, p. 50, 1990.

HANSMANN, Henry; KRAAKMAN, Reinier. Reflections on the end of history for corporate law. In: RASHEED, A.; YOSHIKAW, T. (Ed.). The convergence of corporate governance: promise and prospects. Basingstoke: Palgrave-MacMillan, 2012. p. 32-48.

; . The end of history for corporate law. Georgetown Law Journal, n. 9,

p. 439, 2001.

HARIOU, Maurice. Teoria dell' Instituizone e dela fundazione. A cura di Wivdar Cesare Szforza. Milano: Giuffrè, 1967. 
HASLEM. Managerial opportunism during corporate litigation. The Journal of Finance, v. 60, p. 2013, 2005.

INSTITUTO BRASILEIRO DE GOVERNANÇA CORPORATIVA (IBGC). Pesquisa sobre governança corporativa. Disponível em: <http://www.ibgc.org.br>. Acesso em: 4 out. 2016.

IRTI, Natalino. Direito e mercado. L'ordine giuridico Del mercato. Tradução Rachel Sztajn. 4. ed. Roma: Laterza, 2001.

JENSEN, Michael C. Self-interest, altruism, incentives, and agency theory. Journal of Applied Corporate Finance 7, n. 2, Summer 1994. Disponível em: <https://ssrn.com/abstract=5566>. Acesso em: 10 out. 2017.

. Theory of the firm: governance, residual claims and organizational forms. Journal of Financial Economics, v. 3, n. 4, 1976. Disponível em: <https://ssrn.com/abstract=94043 . Acesso em: 28 out. 2017.

; MECKLING, William H. Theory of the Firm: Managerial Behavior, Agency Costs and Ownership Structure, July 1, 1976.

JUSTEN FILHO, Marçal. O direito das agências reguladoras independentes. São Paulo: Dialética, 2002.

KAHNEMAN, Daniel. Maps of bounded rationality: a perspective on intuitive judgment and choice. Prize Lecture, Dec. 8, 2002. Disponível em: <https://www.nobelprize.org/nobel_prizes/economicsciences/laureates/2002/kahnemann-lecture.pdf>. Acesso em: 9 ago. 2017. . Rápido e devagar: duas formas de pensar. Rio de Janeiro: Objetiva, 2011

KELSEN, Hans. Teoria generale del diritto e dello stato. Milano: Etas, 1964. 
LAMY FILHO, Alfredo. A Lei das S.A: pressupostos, elaboração, aplicação. Rio de Janeiro: Renovar, 1992.

- Considerações sobre a elaboração da Lei de S.A. e de sua necessária atualização. Revista de Direito Bancário e do Mercado de Capitais, v. 51, p. 243, jan. 2011.

. Responsabilidade do administrador por ato praticado no exercício de função: a difícil caracterização do risco envolvido. Temas de S.A. Rio de Janeiro: Renovar, 2007.

; BULHÕES PEDREIRA, José Luiz. A Lei das S.A. Rio de Janeiro: Renovar, 1992.

; A Lei das S.A.: pressupostos, elaboração, aplicação. Rio de Janeiro: Renovar, 1992.

; _ Direito das companhias. Rio de Janeiro: Forense, 2009. v. 1.

LA PORTA, Rafael; LOPEZ DE SILANES, Florencio; SHLEIFER, Andrei. Corporate Ownership around the world. Harvard Institute of Economic Research Paper n. 1840, Aug. 1998. Disponível em: <https://ssrn.com/abstract=103130>. Acesso em: 23 set. 2017.

Governance, Jun. 1999. Disponível em: <https://ssrn.com/abstract=183908>. Acesso em: 12 nov. 2017.

LARENZ, Karl. Metodologia de la Ciencia del Derecho. Tradução de Marcelino Rodríguez Molinero. Barcelona: Ariel, 1994.

LAZZARESCHI NETO, Alfredo Sérgio. Lei das sociedades anônimas anotada. 2. ed. São Paulo: Saraiva, 2008. 
LEÃES, Luiz Gastão Paes de Barros. Pactos parassociais. Revista dos Tribunais, n. 601, p. 40.

LIPTON. The many myths of Lucien Bebchuk. Virginia Law Review, v. 93, p. 733, 2007.

LOBO, Jorge (Coord.). Proporcionalidade com as ações ordinárias, vantagens e preferências. Reforma da Lei das Sociedades Anônimas. Rio de Janeiro: Forense, 2002.

MACEDO, Ricardo Ferreira de. Controle não societário. Rio de Janeiro: Renovar, 2004.

MARGONI, Ana Beatriz Alves; GUERREIRO, Carolina Dias Tavares. Exercício abusivo do poder de controle e o dever de reparar o dano. Direito empresarial e outros estudos de direito em homenagem ao professor José Alexandre Tavares Guerreiro. São Paulo: Quartier Latin, 2013.

MATTOS FILHO, Ary Oswaldo; PRADO, Viviane Muller. Tentativas de desenvolvimento do mercado acionário brasileiro desde 1964. In: LIMA, Maria Lúcia L. M. Pádua (Coord.). Direito e economia: 30 anos de Brasil. São Paulo: Saraiva, 2012. (Série GVLaw, t. 2.)

MAZZILLI, Hugo Nigro. A defesa dos interesses difusos em juízo: meio ambiente, consumidor e outros interesses difusos e coletivos. 12. ed. rev., ampl. e atual. São Paulo: Saraiva, 2000.

MB Associados. Desafios e oportunidades para o Mercado de Capitais brasileiro. Bovespa, 2000. Disponível em: <http://www2.bmf.com.br/cimconteudo/w_livros/mercado_capitais_desafios.pdf >. Acesso em: 24 fev. 2017.

MESSINA, Paulo de Lorenzo; FORGIONI, Paula A. Sociedades por ações: jurisprudência, casos e comentários. São Paulo: RT, 1999. 
MERCADO. Portal do Insper. Quanto vale uma infração? Disponível em: <http://www.insper.edu.br/noticias/quantocustaumainfracao>. Acesso em: 21 abr. 2015.

MODÉ. Reforma do novo mercado fica pela metade. O Estado de S. Paulo, São Paulo, Caderno de Economia, 10 set. 2010. Disponível em: <http://www.estadao.com.br/estadaodehoje/20100910/not_imp607699,0.php>.

MORAES, Luiza Rangel. A pulverização do controle de companhias abertas. Revista de Direito Bancário e do Mercado de Capitais, São Paulo, n. 32, p. 49-84, abr.-jun. 2006.

MUNHOZ, Eduardo Secchi. A importância do sistema de solução de conflitos para o direito societário: limites do instituto da arbitragem. In: YARSHELL, Flávio Luiz et al. (Org.). Processo societário. São Paulo: Quartier Latin, 2012.

Aquisição de controle na sociedade anônima. São Paulo: Saraiva, 2013.

Empresa contemporânea e direito societário: poder de controle acionário e grupos de sociedades. São Paulo: Juarez de Oliveira, 2002.

. Grupos societários de fato. Estrutura de governo e poderes do acionista controlador. In: CASTRO, Rodrigo Monteiro de et al. (Coord.). Direito empresarial e outros estudos de direito em homenagem ao professor José Alexandre Tavares Guerreiro. São Paulo: Quartier Latin, 2013.

NASCIMENTO, João Pedro Barroso; SILVA, Alexandre Couto. Direito societário: estudos sobre a Lei de Sociedade por Ações. São Paulo: Saraiva, 2013.

NEGÓCIOS. Eike causou prejuízo bilionário a bancos, diz jornal. Portal Exame.com. Disponível em: <http://exame.abril.com.br/negocios/noticias/eike-causou-prejuizobilionario-a-bancos-diz-jornal>. Acesso em: 17 jan. 2016. 
OLSON, Mancur. The logic of collective action. Cambridge: Harvard University Press, 1965.

OSTROM, Elinor. Beyond Markets and States: Polycentric Governance of Complex Economic Systems. Prize Lecture, Dec. 8, 2009.

PALEPU, Krishna; HEALY, Paul M. The Fall of Enron. Journal of Economic Perspectives, v. 17, n. 2, Spring 2003. Disponível em: <https://ssrn.com/abstract=417840>. Acesso em: 30 maio 2017.

PARENTE, Norma. Principais inovações introduzidas. In: LOBO, Jorge; KANDIR, Antonio et al. (Coord.). Reforma da Lei das Sociedades Anônimas: inovações e questões controvertidas da Lei $n .^{\circ} 10.303$, de 31.10.2001. Rio de Janeiro: Forense, 2002.

PARGENDLER, Mariana. Responsabilidade civil dos administradores e business judgment rule no direito brasileiro. Revista dos Tribunais, São Paulo, v. 953, p. 51$74,2015$.

. Responsabilidade civil dos administradores e business judgment rule no direito brasileiro. Portal Migalhas. Disponível em: <http://www.migalhas.com.br/arquivos/2015/11/art20151118-08.pdf>. Acesso em: 22 nov. 2017.

. State Ownership and Corporate Governance. Fordham Law Review, v. 80, p. 2917-2973, 2012.

PENTEADO, Mauro Rodrigues. As sociedades de economia mista e as empresas estatais perante a Constituição de 1988. Revista de Direito Industrial, Econômico e Financeiro, v. 73, p. 5.

PEREIRA FILHO, Carlos Roberto. Caso: análise da CAM e do processo de reforma de seu regulamento; No-action letters - "Um novo passo para a CVM?". Portal Valor Econômico, 9 mar. 2015. 
PIMENTA, Guilherme. TJSP instala duas varas empresariais em dezembro. Justiça. Portal Jota. Disponível em: <https://jota.info/justica/tij-sp-instala-duas-varasempresariais-em-dezembro-06102017>. Acesso em: 29 out. 2017.

PITA, Antônio. Economia. Eike Batista. Justiça nega ação civil pública por perdas causadas por Eike Batista a acionistas. Portal Estadão. Disponível em: $<$ http://economia.estadao.com.br/noticias/geral,justica-nega-acao-civil-publica-porperdas-causadas-por-eike-batista-a-acionistas,10000052188>. Acesso em: 20 maio 2016.

PONTES DE MIRANDA, Francisco Cavalcanti. Tratado de direito privado. 4. ed. São Paulo: RT, 1984. t. 49.

PROENÇA, José Marcelo Martins. Insider trading: regime jurídico do uso de informações privilegiadas no mercado de capitais. São Paulo: Quartier Latin, 2005.

. Repúdio ao insider trading. In: SOUZA JUNIOR, Francisco Satiro de (Org.). Mercado de capitais. São Paulo: Saraiva, 2013. v. 1.

; FINKELSTEIN, Maria Eugênia Reis (Org.). Direito societário: gestão e controle. São Paulo: Saraiva, 2008.

REQUIÃO, Rubens. Curso de direito comercial. 16. ed. São Paulo: Saraiva, 1986. v. 2. 25. ed. São Paulo: Saraiva, 2007. v. 2.

RIBAS, Gustavo Santamaria Carvalhal. Das aquisições hostis na prática norteamericana e a perspectiva brasileira. Revista de Direito Mercantil, Industrial, Econômico e Financeiro, São Paulo, n. 141, p. 121-129, jan.-mar. 2006.

RIBEIRO, João Ricardo de Azevedo. Notas sobre a relação de substituição em operações de incorporação envolvendo companhias abertas. In: ROVAl, Armando Luiz; MURRAY NETO, Alberto (Coord.). As sociedades por ações na visão prática do advogado. São Paulo: Elsevier, 2010. 
RIBEIRO, Renato Ventura. Exclusão de sócios nas sociedades anônimas. São Paulo: Quartier Latin, 2005.

ROE, Mark. Political determinants of corporate governance. Oxford: Oxford University Press, 2003.

; BECHUCK, Lucian Arye. A theory of path dependency in corporate governance and ownership. Stanford Law Review, v. 52, p. 781,1999.

ROSSI, Maria Cecília. Espaço regulamentação. Regulador em ação. Estudo aponta aumento substancial de punições da CVM nos últimos anos. Disponível em: $<$ http://www.capitalaberto.com.br/edicoes/mensal/edicao-47/regulador-emacao/\#.VT6XvdJViD8>. Acesso em: 26 abr. 2015.

ROVAI, Armando Luiz. A responsabilidade civil dos administradores das sociedades anônimas e suas repercussões no dia a dia negocial. In: ; MURRAY NETO, Alberto (Coord.). As sociedades por ações na visão prática do advogado. São Paulo: Elsevier, 2010.

SALOMÃO FILHO, Calixto. Deveres fiduciários do controlador. In: . O novo direito societário. 4. ed. São Paulo: Malheiros, 2011.

. Novo estruturalismo jurídico: uma alternativa para o direito? Revista dos Tribunais, São Paulo, v. 101, n. 926, p. 533-548, dez. 2012.

. O novo direito societário. 3. ed. São Paulo: Malheiros, 2006.

4. ed. rev. e ampl. 2. ${ }^{a}$ tiragem, São Paulo: Malheiros, 2015.

. Respostas estruturais para a corrupção empresarial. Valor Econômico, $1{ }^{\circ}$ abr. 2015. Disponível em: <http://www.valor.com.br/opiniao/3987284/respostasestruturais-para-corrupcao-empresarial>. Acesso em: 10 ago. 2015. 
. Teoria crítico-estruturalista do direito comercial. São Paulo: Marcial Pons, 2015.

SCHOUERI, Luis Eduardo. Distribuição disfarçada de lucros. São Paulo: Dialética, 1996.

SHIGUEMATSU, Plínio José Lopes. Mecanismos de proteção e estratégias de defesa em tomadas hostis de controle In: CASTRO, Rodrigo R. Monteiro de; ARAGÃO, Leandro Santos de (Coord.). Direito societário: desafios atuais. São Paulo: Quartier Latin, 2009.

SIGILO EM QUESTÃO. Câmara de Arbitragem da Bovespa rebate críticas. Portal Conjut - Consultor Jurídico. Disponível em: <http://www.conjur.com.br/2013-jun07/camara-arbitragem-bovespa-rebate-criticas-professora-gv>. Acesso em: 2 ago. 2015.

SILVA, Alexandre Couto. Responsabilidade dos administradores de S.A: business judgment rule. Rio de Janeiro: Elsevier, 2007.

SOUZA, Beatriz. Brasil. 8 supostas revelações do escândalo da Petrobras. Portal Revista Exame. Disponível em: <http://exame.abril.com.br/brasil/noticias/8-supostasrevelacoes-do-escandalo-da-petrobras>. Acesso em: 30 set.2015.

SOUZA JUNIOR, Francisco Satiro de. Derivativos de bolsa. In: KUYVEN, Luiz Fernando Martins (Coord.). Temas essenciais de direito empresarial: estudos em homenagem a Modesto Carvalhosa. São Paulo: Saraiva, 2012.

. Dissolução de Sociedades Anônimas. In: FINKELSTEIN, Maria E. R.; PROENÇA, José Marcelo Martins. (Org.). Direito societário: gestão e controle. São Paulo: Saraiva, 2008. p. 152-182.

STIGLER, George J. The theory of economic regulation. Bell Journal of Economic and Management Science, New York, v. 2, n. 1, p. 1-21, Spring 1971. 
STOUT, Lynn A. How Deregulating Derivatives Led to Disaster, and Why ReRegulating Them can Prevent Another. Lombard Street, v. 1, n. 7 July, 10, 2009.

. The Mythical Benefits of Shareholder Control. Virginia Law Review, 2006; UCLA School of Law, Law-Econ Research Paper n. 06-19. Disponível em: <https://ssrn.com/abstract=929530>. Acesso em: 11 jul. 2017.

SZTAJN, Rachel. Acordo de acionistas. In: SADDI, Jairo (Org.). Fusões e aquisições: aspectos jurídicos e econômicos. São Paulo: IOB Thomsom e IBEMEC Law, 2002. p. 288-289.

. Teoria jurídica da empresa: atividade empresária e mercados. São Paulo: Atlas, 2004.

TEIXEIRA, Egberto Lacerda; GUERREIRO, José Alexandre Tavares. Das Sociedades Anônimas no direito brasileiro. São Paulo: José Bushatsky, 1979. v. 2.

THALER, Richard H.; SHEFRIN, H.M. An Economic Theory of Self-Control. Journal of Political Economy, Apr. 1981. Disponível em: $<$ http://faculty.chicagobooth.edu/richard.thaler/research/pdf/an\%20economic\%20theo ry\%20of\%20self-contol.pdf>. Acesso em: 19. set. 2017.

THEODORO JÚNIOR, Humberto. Processo de execução. 22. ed. São Paulo: Universitária de Direito, 2004.

TJSP. Assessoria de imprensa. TJSP instala Câmara Reservada de Direito Empresarial. Portal Jus Brasil. Disponível em: <http://tjsp.jusbrasil.com.br/noticias/2758345/tjsp-instala-camara-reservada-de-direitoempresarial>. Acesso em: 15 jun. 2015

TOLEDO, Paulo Fernando Campos Salles de. Poison pill: modismo ou solução? In: CASTRO, Rodrigo R. Monteiro de; ARAGÃO, Leandro Santos de (Coord.). Direito societário: desafios atuais. São Paulo: Quartier Latin, 2009. 
TORINO, Raffaele. I contratti parasociali. Milano: Giuffrè, 2000.

TORNOVSKY, Miguel. Acordo de acionistas sobre o exercício do poder de controle. Análise das principais alterações introduzidas ao art. 118 da Lei das S.A. pela Lei 10.303/2001. Revista de Direito Mercantil, Econômico e Financeiro, São Paulo, v. 127.

UNITED STATES OF AMERICA. SEC - Security Exchange Commission. Investment Company Act of 1940. Section 2, p. 5. Disponível em: <https://www.sec.gov/about/laws/ica40.pdf>. Acesso em: 19 jul. 2017.

VALENTI, Graziella. "Pílula de veneno" é obstáculo para aquisição da Positivo. Valor Econômico, São Paulo, 10 dez. 2008, Caderno Eu \& Investimentos.

VILLAS BOAS, Bruno. Em cinco anos, CVM aplicou R\$ 1,149 bi em multas, mas arrecadou apenas R\$ 19,4 milhões. Economia. O Globo. Disponível em: <https://oglobo.globo.com/economia/em-cinco-anos-cvm-aplicou-1149-bi-em-multasmas-arrecadou-apenas-194-milhoes-9350355\#ixzz52gE2dP4t>. Acesso em: 13 nov. 2017.

WHALEN, R. Christopher. The subprime crises - cause effects and consequences. Disponível em: <http://ssrn.com/abstract=1113888>. Acesso em: 2 dez. 2017.

WAYNE, Leslie. Business Day/Enron collapse. The New York Times, Jan. 13, 2012. Disponível em: <http://www.nytimes.com/2002/01/13/business/enron-s-collapsebefore-debacle-enron-insiders-cashed-in-1.1-billion-in-shares.html>. Acesso em: 10 jun. 2017.

WALD, Arnoldo. Direito das obrigações. 15. ed. São Paulo: Malheiros, 2000.

; EIZIRIK, Nelson. O regime jurídico das bolsas de valores e sua autonomia frente ao Estado. RDM, v. 61, p. 54-58, 1986 
WIEACKER, Franz. História do direito privado moderno. Tradução portuguesa de A. M. Botelho Hespana. 3. ed. Lisboa: Fundação Calouste Gulbenkian, 2004.

YAZBEK, Otavio. Regulação do mercado financeiro e de capitais. Representações do dever de diligência na doutrina jurídica brasileira: um exercício e alguns desafios. In: KUYVEN, Luiz Fernando Martins (Org.). Temas essenciais de direito empresarial: estudos em homenagem a Modesto Carvalhosa. São Paulo: Saraiva, 2012. 